\title{
Study of Environmental Law Policy in Waste Management
}

\author{
Sita Agustina Siahaan \\ University of Merdeka Malang, Indonesia
}

\begin{abstract}
Handling and management of waste will be more complex and complicated with the increasingly complex type and composition of waste. This study aims to examine environmental law policies in waste management. This research is a normative legal research with a statutory approach. Data were collected by literature study, then analyzed qualitatively. Legal policy in waste management refers to three legal systems which are a combination of components, namely structure, substance, and culture. In addition, environmental law policies in waste management can be studied from two sides, namely preventive and repressive legal policies.
\end{abstract}

Keywords: Legal Policy, Waste Management.

\section{INTRODUCTION}

The economic growth of the Indonesian people from year to year is increasing, followed by population growth. This is increasingly felt its impact on the environment, namely humans tend to damage the environment in order to maintain their lives. The quality of the environment is continuously decreasing, causing environmental degradation problems in people's lives. One of the environmental problems that is still a problem in urban areas is waste management. Garbage is a material that is wasted or disposed of from sources resulting from human and natural activities that do not have economic value. Garbage comes from households, agriculture, offices, companies, hospitals, markets, and so on. Broadly speaking, waste is divided into: Organic/wet waste, Example: Kitchen waste, restaurant waste, vegetable waste, spices or fruit residues and others that can undergo natural decay. Inorganic/dry waste, for example: metal, iron, cans, plastic, rubber, bottles, and others that cannot undergo natural decay. Hazardous waste, Example: Batteries, mosquito repellent bottles, used syringes and others. Waste problems in Indonesia include the increasing number of waste generated by the community, lack of places for garbage disposal, garbage as a place to grow and nests of insects and rats, become a source of pollution and pollution of soil, water and air, become a source and place for germs to live. germs that are harmful to health. and others that cannot undergo natural decay. Hazardous waste, Example: Batteries, mosquito repellent bottles, used syringes and others. Waste problems in Indonesia include the increasing number of waste generated by the community, lack of places for garbage disposal, garbage as a place to grow and nests of insects and rats, become a source of pollution and pollution of soil, water and air, become a source and place for germs to live. germs that are harmful to health. and others that cannot undergo natural decay. Hazardous waste, Example: Batteries, mosquito repellent bottles, used syringes and others. Waste problems in Indonesia include the increasing number of waste generated by the community, lack of places for garbage disposal, garbage as a place to grow and nests of insects and rats, become a source of pollution and pollution of soil, water and air, become a source and place for germs to live. germs that are harmful to health.

In addition to this, in urban communities there is a consumptive culture that influences the improvement of the quality and type of waste. So that waste management cannot be separated from the intervention of the state and various sectors in society, including the business world. In addition, the role of the community which is a network or community of waste disposal also has a big role in waste management in this case is the recycling process so that it can be reused. So that waste management is part of public services that must be regulated in regulations that are expected to provide comfort in the daily lives of citizens.

Policies in the form of regulations in Indonesia are deemed not yet effective in causing a deterrent effect to the community. The problem of waste management has become a crucial problem because the regions (districts/cities) also experience many obstacles in waste management. One of the obstacles regarding the application and enforcement of the law in waste management is part of environmental law enforcement, especially in the application of sanctions.

In Indonesia, there are actually several laws and regulations that have a correlation or are directly related to waste management, namely Law no. 32 of 2009 concerning the Protection and Management of the Environment, Law Number 32 of 2004 concerning Regional Government was replaced with Law no. 23 of 2014 concerning Regional Government, Law no. 18 of 2008 concerning Waste Management and several regional regulations that have been established by local governments at the 
Regency or City level such as Malang City Regional Regulation No. 3 of 2010 concerning Waste Management. The sanctions contained in the regulations, especially those concerning waste management, do not provide a deterrent effect for people who do not carry out waste management with an environmental perspective, so it is necessary to study the effectiveness of sanctions in law enforcement in waste management. In addition, the role of local governments is also very important in issuing policies on waste management. If the region is able to manage its waste properly then the implementation of the principles of Good Environmental Governance can be said to be fulfilled.

The new paradigm views waste as a resource that has economic value and can be used, for example for energy, compost, or for fertilizer. Waste management with the new paradigm is carried out by reducing and handling waste. Waste reduction includes limiting, reusing, and recycling activities, while waste handling includes sorting, collecting, transporting, processing and final processing. The waste problem cannot be solved only by the government. It's time as waste producers we help, even take responsibility for at least taking care of our own waste. The number of households will determine the amount of waste generated. Waste management and transportation is a separate problem that is still difficult to overcome.

\section{LITERATURE REVIEW}

\subsection{Environmental Law Policy}

Environmental law policy is a fundamental part in articulating as well as implementing the values contained in environmental law itself. Not apart from the motion of development and change in all fields, including the development of development and environmental problems, basically environmental law exists not only as an autonomous institution that functions as a means of social control, but also enters into all areas of modern society's life that can be used. as a means of making a change (Fadli et al, 2016).

Environmental law policy in a narrow sense is the determination of concepts, processes, strategies, and tactics that are systematically formulated with regard to plans, programs, projects, and activities of the government and the community as a means of achieving environmental management objectives through the utilization of laws and regulations and their institutions (Rangkuti, 2005). Meanwhile, in a broad sense, that environmental law policy is related to the dimension of wisdom which means a series of legal actions as a tangible manifestation of government authority, or in other words policy is related to development that aims to meet the needs and welfare of the community related to environmental issues.

\subsection{Waste management}

Neolaka (2008) defines waste management as an effort to create beauty by processing waste that is carried out in harmony between the people and the manager or government together. Meanwhile, according to Alex (2012) waste management is an activity that includes the collection, transportation, processing, recycling or disposal of waste materials. In Law Number 18 of 2008 concerning Waste Management, waste management is a systematic, comprehensive, and sustainable activity that includes waste reduction and handling aimed at improving public health and environmental quality and making waste a resource. Management of household waste and similar household waste consists of: (a) waste reduction; and (b) waste management. Where waste reduction in question includes the following activities: (a) limiting waste generation; (b) waste recycling; and/or (c) waste reuse.

\section{RESEARCH METHODS}

This research is descriptive research. The type of research in this writing includes the type of normative legal research. Meanwhile, if viewed from its nature, it includes descriptive research and according to its form, this research is a diagnostic research, namely research that aims to obtain information about the causes of a symptom or several symptoms. The type of data used in this study is secondary data, namely data or information from the review of similar research documents that have been done before, library materials such as books, literature, newspapers, magazines, journals or archives that are in accordance with the research to be discussed. . The type of research data used is secondary data in the field of law in terms of binding strength which can be divided into 3 (three), the authors use the following data as primary, secondary and tertiary legal materials. Data collection techniques are carried out by studying literature to collect and compile data related to the problem under study. The data obtained in this paper are qualitative, so the analysis in this paper is qualitative data analysis with a problem approach, namely the Statute Approach. In this case, a normative research must use a statutory approach, because what will be studied are various legal rules which are the focus as well as the central theme of a research. Data collection techniques are carried out by studying literature to collect and compile data related to the problem under study. The data obtained in this paper are qualitative, so the analysis in this paper is qualitative data analysis with a problem approach, namely the Statute Approach. In this case, a normative 
research must use a statutory approach, because what will be studied are various legal rules which are the focus as well as the central theme of a research. Data collection techniques are carried out by literature studies to collect and compile data related to the problem under study. The data obtained in this paper are qualitative, so the analysis in this paper is a qualitative data analysis with a problem approach, namely the Statute Approach. In this case, a normative research must use a statutory approach, because what will be studied are various legal rules which are the focus as well as the central theme of a research.

\section{RESULTS AND DISCUSSION}

The problem of waste is very important. Garbage is a matter related to the culture and behavior of the community, especially in urban areas. For this reason, proper waste management is needed in accordance with existing laws and regulations. The problem of waste is an important problem in various urban areas (especially) which are densely populated. This is because most people still view that waste is the rest of the use of an item, both organic and inorganic, that cannot be utilized. So that the community in managing waste still relies on end-of-pipe, namely waste is collected, transported, and disposed of to the final waste processing site. Whereas, Heaps of waste with large volumes at the location where the final waste is processed have the potential to release methane gas $(\mathrm{CH} 4)$ which can increase greenhouse gas emissions and contribute to global warming. In order for the landfill to be decomposed through natural processes, it takes a long period of time and requires handling at a large cost. In waste management, the government and local governments require policies in the field of regulations that are based on regulations at the national and regional levels, these regulations include:

1) Article $28 \mathrm{H}$ paragraph (1) of the 1945 Constitution of the Republic of Indonesia

Article 28H paragraph (1) of the 1945 Constitution of the Republic of Indonesia gives the right to everyone to have a good and healthy living environment. The article gives the consequence that the government is obliged to provide public services in waste management. This has legal consequences that the government is the authorized and responsible party in the field of waste management. Although waste management is the government's obligation, it can also involve the business world and the community who are engaged in the solid waste sector. In the context of implementing integrated and comprehensive waste management, fulfilling the rights and obligations of the community, as well as the duties and authorities of the Government and regional governments to carry out public services, a legal umbrella is needed in the form of a law.

2) Law Number 32 of 2004 concerning Regional Government is repealed by Law Number 23 of 2014 concerning Regional Government

With the granting of the widest possible autonomy to regions, it is directed to accelerate the realization of community welfare through service improvement, empowerment, and community participation. So that the authority in waste management is a service provided by the local government by empowering the community and managing waste based on community participation.

3) Law No. 32 of 2009 concerning Environmental Protection and Management (UUPPLH)

The fulfillment of a good and healthy environment is a human right and a constitutional right for every Indonesian citizen. Therefore, the government, regional governments and all stakeholders are obliged to protect and manage the environment in the implementation of sustainable development so that the Indonesian environment can remain a source and life support for the Indonesian people and other living creatures. So that good and correct waste management is a manifestation of the fulfillment of a good and healthy environment.

4) Law No. 18 of 2008 concerning Waste Management

In the Waste Management Act, it is based on the large population of Indonesia with a high growth rate resulting in an increase in the volume of waste. In addition, people's consumption patterns contribute to creating increasingly diverse types of waste, including packaging waste that is dangerous and/or difficult to decompose by natural processes. The substance of this law is directly related to waste management, namely Article 19 which regulates the management of household waste and waste similar to household waste. The article states that the management of household waste and similar household waste consists of reducing waste and handling waste.

Waste management is the collection, transportation, processing, recycling or disposal of waste materials. It refers to waste materials that are generated from human activities, and are usually managed to reduce their impact on health, the environment, or aesthetics. Waste management is also carried out to restore natural resources (resources recovery). Waste management can involve solid, liquid, gaseous, or radioactive substances with specific methods and skills for each type of substance. 
In raising public awareness in waste management, law enforcement is needed. Therefore, law is a means that contains values and concepts about justice, truth, social benefits and so on. So that the existence of a law enforcement is an activity to harmonize the relationship of values that are outlined in the principles/views of values that are solid and manifest and act as a series of final stages of value translation to create (as "social engineering"), maintain and maintain (as "social engineering"). social control") peaceful social life (Ridwan, 2011). In addition, environmental law enforcement is an act and/or process of coercion to obey the law based on statutory provisions and/or environmental requirements (Arifin, 2009). So that environmental law enforcement in the field of waste management as an effort to apply positive law in people's lives so that the Law no. 18 of 2008 concerning Waste Management and regional regulations regarding waste management which aim to maintain and maintain environmental conditions so that the community gets a good and healthy environment.

The waste problem in various cities in Indonesia can be solved properly if the active role of the community increases. In general, the waste management process on a communal basis consists of several process stages, including:

1) Strive for waste to be managed, sorted and processed at an early stage starting from the waste generation site itself (in this case the majority is the household environment). This effort can at least reduce the generation of waste that must be collected and transported to the TPS so that the burden is reduced.

2) In the initial phase at the household level, at least efforts are made to process organic waste into compost and inorganic waste is sorted and collected according to its type so that it is possible to recycle. TPS empowerment needs to be improved by making IPSO there to assist the management in each household. Observing the condition of TPS in several regencies/cities in Indonesia, it is known that each inorganic waste has economic value.

3) The next stage is the processing of waste that is not possible to be processed in every household environment that has a TPS. The existing TPS using this approach was later converted into a kind of integrated waste processing plant, whose processed products are compost, recycled materials and waste that cannot be processed anymore.

4) The final stage is the transportation of the final waste, waste that cannot be recycled or cannot be reused at the TPS, around 10$20 \%$ of the waste goes to the TPA. In this phase, the final landfilling or burning process can be carried out using an incinerator.

Based on the process stages above, the key to community-based (communal) waste management actually lies in the process chain at the household level and at the kelurahan/village level (ie at the TPS). Which involves directly the community as a plus manager (owner of home industry). Without this communal system, it is impossible for waste to be completely or sustainably handled. How to handle like this actually aims to:

1) Cultivate a good way of disposing of waste starting from the household environment to the TPS by using crackle/garbage box.

2) Organizing TPS to become a center for maximum utilization of organic and inorganic waste.

3) Turning organic and inorganic waste left over from management at the communal level into raw materials for power generation and biogas based on municipal waste.

4) This communal-based waste management program will definitely cut the waste distribution chain from TPS to TPA.

5) Creating new businesses at the community level, which will eventually become self-reliant in managing their own waste.

Waste management practices differ between developed and developing countries, also differ between urban areas and rural areas and between residential areas and industrial areas. Management of non-hazardous waste from residential and institutional areas in metropolitan areas is usually the responsibility of local governments, while waste from commercial and industrial areas is usually handled by waste processing companies.

There are 4 principles that can be used to address the problem of waste management and utilization. These four principles are better known as the 4Rs which include:

1) Reduce, is an environmental conservation action by reducing the use of items that are less necessary, one example we should be able to reduce the use of styrofoam to wrap food, we can use food containers that come from paper or plastic so that they are easy to recycle again, a little information that styrofoam is a material that can not be recycled.

2) Reuse, is a way of preserving the environment by reusing an item, as much as possible choose items that can be reused. Avoid using disposable items (one time use, throw away). This can extend the time the item is used before it becomes trash.

3) Recycle, is a way of preserving the environment by recycling an item, for example we can recycle organic waste in our homes into compost, and others. 
4) Replace, is a way of preserving the environment by replacing goods that can only be used once with goods that are more durable. Use items that are more environmentally friendly, such as plastic crackle bags with baskets when shopping. In principle, the utilization of household waste is carried out in advance by separating or sorting organic waste and inorganic waste, so that the management and utilization process is easier.

The government's efforts in law enforcement in the field of waste management are indeed the biggest factor in society's culture. In line with the notion of law as a legal system, among others, Lawrence M. Friedman said that a legal system in actual operation is a complex organism in which structure, substance, and culture interact. The explanation of each element is Structural components, namely institutions created by the legal system with various functions in order to support the operation of the system. This component makes it possible to see how the legal system provides services for the cultivation of legal materials on a regular basis. The substantive component is the output of the legal system, in the form of regulations, decisions used by both the regulating and regulated parties. The cultural component which consists of values and attitudes that affect the operation of the law (can be positive and can be negative), or by Friedman is called legal culture. This legal culture functions as a bridge that connects the rule of law with the legal behavior of all citizens or as a "motor driving force of justice". This cultural component should be distinguished between the internal legal culture, namely the legal culture owned by the legal structure, and the external legal culture, namely the legal culture of the wider community (Warasih, 2005). Based on these components, the legal structure in the sense that the government and local governments have a major role in law enforcement efforts in the field of waste management, both preventively and repressively.

The legal policy in the field of waste management contained in the Malang Regency Regional Regulation No. 2 of 2018 concerning Waste Management regulates administrative sanctions in the form of verbal warnings, written warnings, government coercion; forced money; license revocation; and/or closing of business/activity. In addition, it also applies criminal sanctions with a maximum imprisonment of 3 (three) months or a maximum fine of Rp. 50,000,000.00 (fifty million rupiahs). Efforts related to the provision of administrative sanctions or criminal sanctions are repressive legal policies, while the supervision regulated in administrative environmental law has a preventive function and a corrective function (Rahmadi, 2011). The form of the preventive function in the form of supervision aims to prevent violations of norms, standards, procedures, and criteria related to waste management.

\section{CONCLUSIONS AND SUGGESTIONS}

\subsection{Conclusion}

Regulations regarding waste management in Indonesia are regulated in regulations at the central and regional levels. Regulations at the central level that have a correlation to waste management and are directly related to waste management, namely Law no. 32 of 2009 concerning Environmental Protection and Management, Law Number 23 of 2014 concerning Regional Government, Law no. 18 of 2008 concerning Waste Management and several regional regulations that have been established by local governments both at the Regency/City level, for example Malang City Regional Regulation No. 3 of 2010 concerning Waste Management.

Enforcement of environmental law in the field of waste management refers to 3 legal systems which are a combination of components, namely structure, substance and culture. In addition, related to law enforcement in waste management, it can be studied from two sides, namely preventive and repressive law enforcement. Law enforcement in waste management is also an embodiment of the government and local governments in applying the principles of Good Environmental Governance with the aim of raising public awareness of the importance of waste management.

\subsection{Suggestion}

Indonesia already has various regulations regarding waste management so that the effectiveness of environmental law enforcement can be carried out preventively by involving the community with programs related to waste management so as to be able to raise public awareness of the importance of a good and healthy environment. Programs that can be carried out by the Government and Regional Governments with community-based management, for example by the existence of waste networks and waste banks so that the community's mindset is that waste is able to provide benefits and income.

\section{REFERENCES}

Alex S. 2012. Success in Processing Organic Waste Into Organic Fertilizer. Yogyakarta: New Press Library.

Fadli, Moh, Mukhlish and Mustafa Lutfi. 2016. Law and Environmental Policy. UB Press. Poor.

Malang Regency Regional Regulation No. 2 of 2018 concerning Waste Management. 
Mulyanto. 2013. Integrated Waste Management System (Sipengestu) Serengan Village in the Study of Sociology of Law. Parental Journal. Volume I Number 2.

Neolaka, Amos. 2008. Environmental Awareness. Jakarta: Rineka Cipta.

Rahmadi, Takdir. 2011. Environmental Law in Indonesia. Jakarta : PT. Rajagrafindo Persada.

Rangkuti, Siti Sundari, 2005. Environmental Law and National Environmental Policy, Third Edition, Publisher Airlangga University Press, Surabaya.

Ridwan HR. 2011. Revised Edition of State Administrative Law. Jakarta : PT. Grafindo Persada.

Syamsul Arifin. 2012. Environmental Protection and Management Law in Indonesia. Jakarta : PT Softmedia.

Law Number 18 of 2008 Concerning Waste Management.

Law Number 23 of 2014 Concerning Regional Government

Law Number 32 of 2009 Concerning Environmental Protection and Management.

Warasih, Esmi. 2005. Legal Institutions, A Sociological Study. Semarang : PT Suryandaru Utama. 